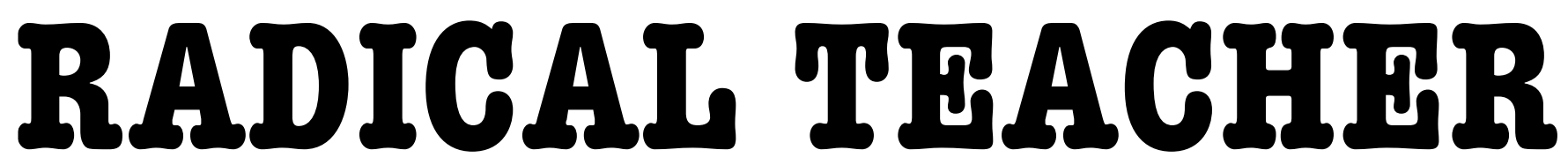

A SOCIALIST, FEMINIST, AND ANTI-RACIST JOURNAL ON THE THEORY AND PRACTICE OF TEACHING

\title{
In Love and Trouble: Stories of Black Women
}

(RADICAL TEACHER NO.15, 1980)

by Deborah Rosenfelt

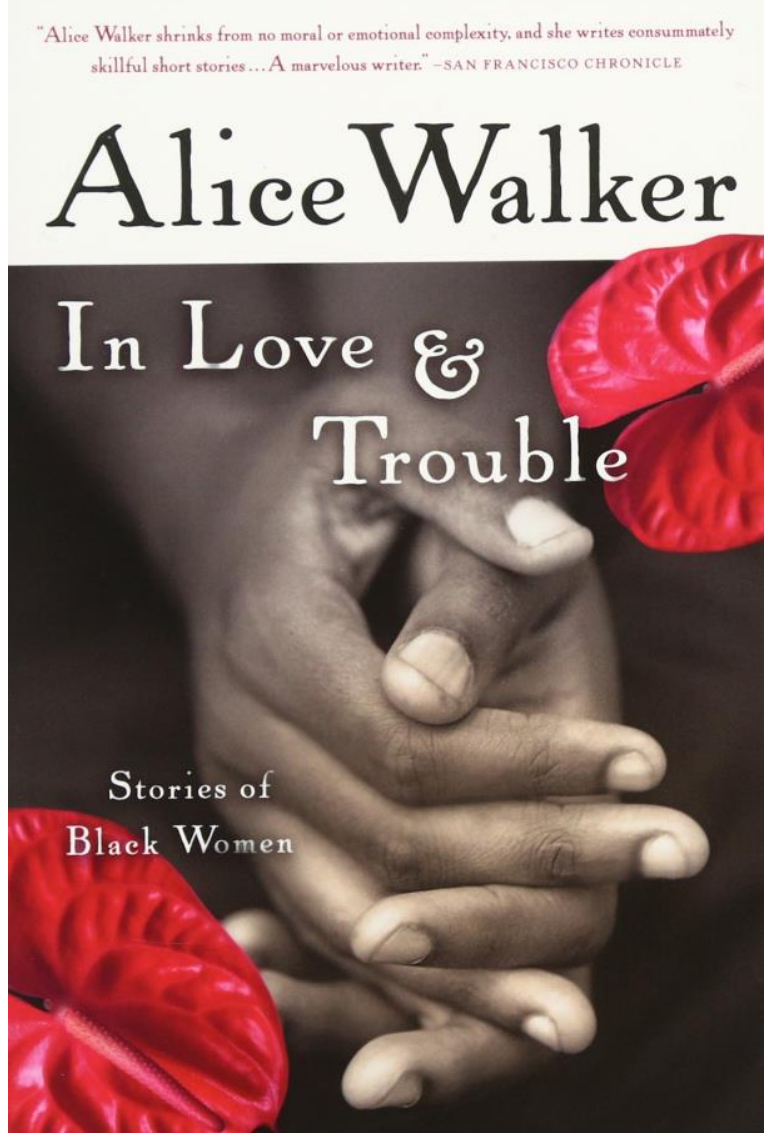

IN LOVE \& TROUBLE: STORIES OF BLACK WOMEN (MARINER BOOKS, 2003) 
In Love and Trouble: Stories of Black Women. Alice Walker. Harcourt, Brace.

T hese stories portray the sufferings and strengths of Black women in a wide variety of roles: from the oldfashioned Christian of "The Welcome Table" to the cultural nationalist poet of "Entertaining God"; from the frustrated hairdresser of "Her Sweet Jerome" to the strong farm woman-mother of "Everyday Use"; from the rootwoman of "The Revenge of Hannah Kemhuff" to the doctoral candidate of "To Hell with Dying"; from the garment industry worker "Roselily" to the writer of "Really, Doesn't Crime Pay?" This range led one of my students to remark, "I'll never say 'the Black woman' again."

In these stories, the Southern penchant for the grotesque and the Gothic becomes a revelation of the injuries inflicted on human personality and human relationships by racism, sexism, and the barriers of class. The stories grow out of a dialectic vision: they are structured around the contradictions between the old and the new (the old South, the old Negro; the new South or the urban North, the new Afro-American); between tradition and progress; between tradition as a source of strength and tradition as a source of oppression; between the lived realities of Black life in America and the theories of Black nationalism and Black revolution.

I have used this book for a number of years in upperdivision classes in Women and Literature and Literature and Social Change, though it would be appropriate for any courses in contemporary American literature and/ or the short story. Usually, I ask each student ahead of time to pick one story s/he particularly likes to "teach" to the rest of the class. The students, mostly white, mostly from blueand white-collar families, find them both instructive and moving. They enjoy analyzing the similarities and differences between the women's experiences here and those in works by white women writers and Black male writers. The content, while teaching something about Black culture, challenges their often stereotypical notions about Black women, as does Walker's sheer virtuosity as a writer. For, though the prose style is simple and accessible even to weak readers, the array of techniques -- variations in point of view, the uses of dialogue, a tonal range from irony to compassion, a control of image -- make them fun to analyze as literature too.

\footnotetext{
$(\mathrm{Cc})$ BY-NC-ND

This work is licensed under a Creative Commons Attribution-Noncommercial-No Derivative Works 3.0 United States License.

ULIS D-Sonk

This journal is published by the University Library System of the University of Pittsburgh as part of its D-Scribe Digital Publishing Program, and is cosponsored by the University of Pittsburgh Press.
} 